\title{
Analisis Orientasi Pasar dan Orientasi Kewirausahaan Terhadap Kinerja Pemasaran dan Inovasi UMKM Binaan KPw Bank Indonesia Provinsi Riau
}

\author{
Hanif $^{1^{*}}$, Zulkarnain ${ }^{2}$, Eka Armis Pailis ${ }^{3}$ \\ 1,2,3 Program Pascasarjana Universitas Riau, Kota Pekanbaru, Provinsi Riau, \\ Indonesia.
}

\begin{abstract}
Abstrak. UMKM Indonesia sebagai penyerap tenaga kerja terbesar diharapkan mampu menumbubkan pasar ekspor. Provinsi Riau merupakan daerah di pulau Sumatera yang memiliki indeks pangsa pasar terendah. Penelitian ini bertujuan untuk menguji lebih lanjut apakah orientasi kewirausahaan dan orientasi pasar berpengaruh terhadap inovasi dan kinerja pemasaran. Penelitian ini merupakan penelitian eksplanatori. Unit analisis dalam penelitian ini adalah klaster UMKM binaan Bank Indonesia di Provinsi Riau di Provinsi Riau. Analisis yang digunakan adalab Partial Least Square (PLS). Total populasi dalam penelitian ini adalab 277 UMKM dengan sampel 164 UMKM dari berbagai cluster. Teknike pengumpulan data dalam penelitian ini menggunakan kuesioner yang dikumpulkan berupa data primer. Hasil penelitian ini menunjukkan bahwa orientasi pasar berpengaruh signifikan terhadap inovasi usaha, orientasi kewirausahaan berpengaruh signifikan terhadap inovasi usaba, orientasi pasar berpengarub signifikan terbadap peningkatan kinerja pemasaran, orientasi kewirausahaan berpengarub signifikan terhadap kinerja pemasaran, inovasi usaha berpengaruh signifikan terhadap kinerja pemasaran, orientasi pasar berpengaruh signifikean terbadap kinerja pemasaran melalui inovasi bisnis, orientasi kewirausahaan berpengaruh signifikean terbadap kinerja pemasaran melalui inovasi bisnis.
\end{abstract}

Kata kunci: Orientasi Pasar; Orientasi Kewirausahaan; Kinerja Pemasaran; Inovasi Umkm.

\begin{abstract}
Indonesian MSMEs as the largest absorber of labor are expected to grow the export market. Rian Province is the area on the island of Sumatra that has the lowest market share index. This study aims to further test whether entrepreneurial orientation and market orientation bave an effect on innovation and marketing performance. This research is explanatory research. The unit of analysis in this study is the MSME cluster fostered by Bank Indonesia in Riau Province in the Rian Province. The analysis used is Partial Least Square (PLS). The total population in this study was 277 MSMEs with a sample of 164 MSMEs from various clusters. Data collection techniques in this study used a questionnaire collected in the form of primary data. The results of this study indicate that market orientation has a significant effect on business innovation, entrepreneurial orientation has a significant effect on business innovation, market orientation has a significant effect on improving marketing performance, entrepreneurial orientation has a significant effect on marketing performance, business innovation has a significant effect on marketing performance, market orientation has a significant effect on marketing performance through business innovation, entrepreneurial orientation has a significant effect on marketing performance through business innovation.
\end{abstract}

Keywords: Market Orientation; Entrepreneurial Orientation; Marketing Performance; MSME Innovation. 


\section{Pendahuluan}

Pelaku usaha harus memiliki strategi dalam pengembangan usahanya agar dapat menimbulkan peluang bagi usaha tersebut untuk memasuki pasar luar maupun dalam negeri. Semakin meningkatnya pertumbuhan UMKM di Negara Indonesia, menyebabkan wilayah UMKM saat ini telah menyebar sampai ke pelosok daerah. Kementerian UKM dan Koperasi RI menyatakan bahwa secara jumlah unit, UMKM memiliki pangsa sekitar 99,99\% (62.9 juta unit) dari total keseluruhan pelaku usaha di Indonesia (2017), sementara usaha besar hanya sebanyak $0,01 \%$ atau sekitar 5400 unit. Pembinaan dan pelayanan kepada UMKM yang diberikan selama ini oleh perbankan atau lembaga terkait lainnya atas kebijakan yang diatur oleh Bank Sentral telah banyak membantu perkembangan UMKM dan bangkit dari permasalahan-permasalahan. Undangundang nomor 23 tahun 1999 (UU) tentang Bank Indonesia, yang disempurnakan dengan Undang-undang nomor 3 tahun 2004 tentang Bank Sentral, lembaran baru telah dibuka dalam membantu pengembangan UMKM di Indonesia melalui peran Bank Indonesia. Memelihara dan mencapai kestabilan nilai rupiah adalah misi atau tujuan dari Bank Indonesia. Nilai tukar yang wajar, serta inflasi yang melaju dengan stabil dan rendah merupakan cerminan dari kestabilan nilai rupiah, merupakan salah satu syarat agar terciptanya pertumbuhan ekonomi yang berkelanjutan sehingga ketika giliran sudah datang kesejahteraan rakyat dapat meningkat.

Berdasarkan indeks pangsa pasar UMKM di berbagai Provinsi di Sumatera terlihat bahwa terdapat beberapa Provinsi yang memiliki pangsa output ter-rendah se-Indonesia. Indeks pangsa pasar tertinggi adalah Aceh, sedangkan indeks pangsa pasar terendah adalah Provinsi Riau. pangsa pasar UMKM di Riau yang kurang bersaing dikarenakan banyaknya barang impor yang masuk ke Riau. Menurut data sekitar 49\% barang impor berasal dari Malaysia, berdasarkan data dari Dinas Perdagangan (Disperindag) dan Perindustrian Provinsi Riau. UMKM yang ingin sukses dalam lingkup persaingan yang ketat harus mampu meningkatkan kinerja pemasarannya. Berdasarkan wawancara dengan klaster binaan
Bank Indonesia diketahui bahwa terdapat fluktuasi (naik-turun) produksi UMKM. Salah satu faktor tidak berwujud dari orientasi pasar adalah memiliki pengaruh pada kinerja perusahaan. Perusahaan yang akan mendapatkan kinerja yang lebih bagus dalam memahami pesaing dan pelanggannya adalah perusahaan yang berorientasi pasar. Penerapan orientasi pasar akan menciptakan hubungan yang lebih harmonis dengan pelanggan yang bisa meningkatkan pangsa pasar, profit, hasil kinerja penjualan dan pertumbuhan.

Beberapa literatur manajemen untuk proses manajemen kewirausahaan menunjukkan dasar dimensi dari kecenderungan organisasional, yakni sikap proaktif, kemampuan inovasi, dan kemampuan mengambil resiko. Namun terdapat kesenjangan penelitian pada variabel orientasi kewirausahaan ini, diketahui bahwa orientasi kewirausahaan terhadap kinerja pemasaran tidak memiliki pengaruh positif secara signifikan. Ketidakkonsistenan hasil penelitian terdahulu mendorong penulis untuk menambahkan variabel inovasi sebagai variabel intervening/mediasi. Hal ini dasari oleh pendapat Altuntas et al. (2013) "menjelaskan bahwa inovasi akan memiliki peran sebagai mediator dalam mendorong kinerja dan sangat bergantung pada orientasi pasar." Selain itu penelitian terdahulu seperti Leal-Rodríguez \& Albort-Morant (2016), Asashi \& Sukaatmadja (2017) dan Yadav, Tripathi \& Goel (2019) menjelaskan bahwa orientasi pasar berdasarkan inovasi sebagai variabel intervening mempunyai dampak positif terhadap kinerja pemasaran. Namun belum adanya model penelitian yang menambahkan variabel kewirausahaan sebagai variabel independen lain yang juga diuji secara bersama-sama pengaruhnya dengan efek mediasi dari inovasi terhadap kinerja pemasaran.

Penelitian terdahulu dengan penelitian ini mempunyai kesamaan. Pertama, kesamaan berada pada dugaan bahwa orientasi pasar serta orientsi kewirausahaan memiliki dampak terhadap kinrja pemasaran. Kedua, terdapat pada inovasi merupakan variabel mediasi dalam orientasi pasar berpengaruh terhadap kinerja pemasaran. Ketiga, kesamaan dalam penelitian terdahulu juga ada pada alat analisis yang digunakan, yaitu untuk menganalisis masih 
memakai analisis data pada pengaruh inovasi, orientasi kewirausahaan dan orientasi pasar terhadap kinerja pemasaran. Oleh karena itu pengujian lebih lanjut perlu dilakukan mengenai apakah orientasi kewirausahaan dan orientasi pasar mempunyai pengaruh terhadap inovasi dan kinerja pemasaran.

\section{Tinjauan Literatur}

\section{Pengaruh Orientasi Pasar Terhadap Inovasi}

Suliyanto \& Rahab (2012) bahwa orientasi pasar pada UKM di Kabupaten Banyumas mempunyai dampak positif kepada inovasi di daerah tersebut. Altuntas et al. (2013) menjelaskan adanya orientasi pasar memiliki dampak positif kepada inovasi yang ada di negara Turki dalam bidang organisasi kesehatan swasta. Penelitian Pardi et al. (2014) menjelaskan bahwa orientasi pasar mempunyai dampak positif terhadap inovasi di UKM Batik Jawa Tengah. Suendro (2010) menjelaskan bahwa orientasi pasar (koordinasi lintas-fungsi, orientasi pesaing dan orientasi pelanggan) memiliki dampak positif kepada inovasi produk pada Industri Menengah dan Industri Kecil Batik Pekalongan.

H1 : Orientasi pasar berpengaruh signifikan terhadap inovasi UMKM klaster Binaan KPw Bank Indonesia Provinsi Riau.

\section{Pengaruh Orientasi Kewirausahaan Terhadap Inovasi}

Penelitian terdahulu yang dilakukan Hult (2004) menjelaskan bahwa orientasi kewirausahaan mempunyai dampak signifikan terhadap inovasi, penelitian ini juga didukung oleh Ejdys (2015) bahwa pengambilan resiko dalam perusahaan tidak berhubungan dengan inovasi. Sedangkan penelitian yang dikerjakan oleh Lin et al., (2008) bahwa orientasi kewirausahaan tidak mempunyai dampak yang signifikan terhadap inovasi.

H2: Orientasi kewirausahaan berpengaruh signifikan terhadap inovasi UMKM klaster Binaan KPw Bank Indonesia Provinsi Riau.

\section{Pengaruh Orientasi Pasar Terhadap Peningkatan Kinerja Pemasaran}

Teori-teori manajemen pemasaran menyatakan bahwa perkembangan filosofi manajemen pemasaran yang lebih berfokus pada pasar bisa mempengaruhi kinerja pemasaran yang dijalankan oleh perusahaan untuk mendorong adanya bauran pemasaran (marketing mix). Perkembangan teori orientasi pasar yang dilakukan oleh Kohli \& Jawkorsi (1990), Jawkorsi \& Kohli (1993), Narver \& Slater (dalam Ferdinand 2014) menyatatakan bahwa "orientasi pasar yang diaktualisasi berdasarkan informasi pesaing, informasi pelanggan yang dikembangkan serta pendistribusian pada semua lini organisasi perusahaan perihal informasi pasar pada umumnya bisa mendatangkan sebuah jalur stratejik untuk mendapatkan kinerja pasar yang baik melalui upaya-upaya untuk memuaskan kebutuhan dan pengenalan kebutuhan pelanggan” (Manek, 2013).

Hasil penelitian Ahimbisibwe et al. (2013) menemukan dampak positif antara orientasi pasar terhadap kinerja pada perusahaan. Selain itu temuan dari Altuntas et al. (2013), Anggraini et al. (2014), Charles et al. (2012) \& (Setiawan, 2015) menjelaskan bahwa orientasi pasar mempunyai dampak positif terhadap kinerja pemasaran suatu usaha atau industri.

H3: Orientasi pasar berpengaruh signifikan terhadap kinerja pemasaran UMKM klaster Binaan KPw Bank Indonesia Provinsi Riau.

\section{Pengaruh Orientasi Kewirausahaan Terhadap Peningkatan Kinerja Pemasaran}

Variabel orientasi kewirausahaan dapat mempengaruhi kinerja pemasaran. Porter (2008) mendefinisikan strategi benefit perusahaan sebagai bentuk orientasi kewirausahaan agar mampu bersaing di dalam market place yang sama dengan cara yang lebih efektif. Orientasi kewirausahaan mengarah kepada pengambilan keputusan, praktik, dan proses yang mengarahkan ke arah masukan baru serta memiliki tiga aspek kewirausahaan, yaitu selalu inovatif, bertindak dengan proaktif serta berani mengambil risiko (Lumpkin \& Dess, 1996). Pada hakikatnya kemampuan dalam diri seseorang adalah proses belajar yang menghubungkan berbagai bagian seperti pengetahuan, sikap dan keterampilan (Nadle, 1992 \& Thonthowi, 1991).

Beberapa penelitian terdahulu menjelaskan hubungan antara variabel kinerja pemasaran 
terhadap orientasi kewirausahaan. Berdasarkan penelitian yang dilakukan oleh Fatmawati et al. (2016), orientasi kewirausahaan mampu mempengaruhi kinerja pemasaran secara signifikan. Begitu juga berdasarkan penelitian yang dilakukan oleh Yeni et al. (2014) bahwa orientasi kewirausahan dapat mempengaruhi kinerja pemasaran. Selanjutnya, beberapa penelitian yang lain juga menyatakan hal yang sama dimana orientasi kewirausahaan bisa mempengaruhi kinerja pemasaran yang dapat mengalami penurunan ataupun peningkatan (Gholami \& Birjandi, 2016); Guspul (2016); Ibrahim \& Mahmood (2016); Mustikowati \& Tysari (2014).

H4: Orientasi kewirausahaan berpengaruh terhadap kinerja pemasaran UMKM klaster Binaan Bank Indonesia Provinsi Riau.

\section{Pengaruh Inovasi Terhadap Peningkatan Kinerja Pemasaran}

Lukas serta Ferrel dalam Wachjuni (2014) menjelaskan bahwa inovasi dan pemasaran dipandang sebagai komponen utama dari keunggulan bersaing dan sebagai pendorong pertumbuhan ekonomi. Wahyono (2002) memberikan dua konsepsi inovasi yaitu 1) keinovatifan serta 2) kapasitas untuk berinovasi. Kapasitas dalam berinovasi merupakan keahlian perusahaan dalam menerapkan ataupun menggunakan produk baru, proses, atau gagasan secara berhasil. Sedangkan keinovasian adalah tentang adanya gagasan baru yang diterima oleh keterbukaan fikiran sebagai sebuah kultur dalam perusahaan.

Tung (2012) menjelaskan bahwa inovasi produk memiliki pengaruh positif kepada kinerja. Penelitian terdahulu seperti Suliyanto \& Rahab, (2012); Altuntas et al. (2013); Pardi et al. (2014); Killa (2014) dan Oktavio, Kaihatu \& Kartika (2019) menjelaskan bahwa inovasi mempunyai dampak positif terhadap kinerja pemasaran. Pada unit analisis UMKM beberapa temuan seperti Suendro (2010); Maslucha \& Sanaji (2013) dan Utaminingsih (2016) mejelaskan adanya inovasi produk mempunyai dampak positif kepada kinerja pemasaran.

H5: Inovasi berpengaruh siginifikan terhadap kinerja pemasaran UMKM klaster Binaan Bank Indonesia Provinsi Riau.

\section{Pengaruh Orientasi Pasar Terhadap Peningkatan Kinerja Pemasaran Melalui Inovasi Sebagai Variabel Intervening}

Setyawati et al., (2020) "menyatakan bahwa inovasi mampu memediasi antara orientasi pasar terhadap kinerja. Inovasi adalah variabel mediator antara orientasi pasar terhadap kinerja dari pemasaran" (Yadav, Tripathi \& Goel (2019). Pardi et al., (2014) menjelaskan bahwa orientasi pasar di UKM Batik jika dimediasi oleh inovasi dapat memberikan hasil yang signifikan kepada kinerja pemasaran, yang bisa disimpulkan kinerja pemasaran UKM Batik sangat bergantung pada tingkatan orientasi pasar serta tingkat inovasi perusahaan yang berpengaruh pada inovasi. Altuntas et al. (2013) menjelaskan bahwa inovasi sangat bergantung kepada orientasi pasar dan dapat bermain peran sebagai mediator supaya dapat mengarahkan kinerja. Hasil penelitian Leal-Rodríguez and Albort-Morant (2016) Ashahi \& Sukaatmadja (2017) dan Yadav, Tripathi \& Goel (2019) menjelaskan bahwa orientasi pasar mempunyai pengaruh positif melalui inovasi sebagai variabel intervening terhadap kinerja pemasaran.

H6: Orientasi pasar berpengaruh siginifikan terhadap peningkatan kinerja pemasaran melalui inovasi UMKM klaster Binaan Bank Indonesia Provinsi Riau.

\section{Pengaruh Orientasi Kewirausahaan Terhadap Peningkatan Kinerja Pemasaran Melalui Inovasi Sebagai Variabel Intervening}

Menurut Boehm (2008) orientasi kewirausahaan sendiri memiliki definisi yang mengacu pada pengambilan keputusan, praktik, dan proses yang mengarahkan kearah input baru serta memiliki tiga aspek kewirausahaan, yaitu selalu inovatif, berani mengambil resiko dan bertindak dengan proaktif, ini melibatkan tindakan serta niat yang berguna pada proses generatif yang dinamis dibutuhkan dalam penciptaan usaha baru. Menurut Swoboda \& Foscht (2014) bertindak secara proaktif, selalu inovatif, pengambilan resiko, dan mencerminkan kecenderungan perusahaan untuk berperilaku inovatif dan terlibat dalam pengambilan risiko demi tercapainya tujuan strategi termasuk ke dalam bagian dari orientasi kewirausahaan. 
Hasil penelitian Grinstein (2008) dan Sukaryawan (2013) menemukan bahwa inovasi merupakan yang menjabarkan bahwa orientasi kewirausahaan merupakan perwujudan dari inovasi proses serta produk. Selanjutnya penelitian Gradistya \& Farida (2016), Prihatin, Surya \& Suhendra (2017) menemukan bahwa inovasi merupakan variabel mediasi dari orientasi kewirausahaan kepada kinerja pemasaran.

H7: Orientasi kewirausahaan berpengaruh signifikan terhadap peningkatan kinerja pemasaran melalui inovasi UMKM klaster Binaan Bank Indonesia Provinsi Riau.

\section{Metodologi Penelitian}

Penelitian ini bersifat explanatory research. Unit analisis pada penelitian ini adalah UMKM klaster Binaan Bank Indonesia Provinsi Riau di wilayah Provinsi Riau, analisis yang digunakan adalah Partial Least Square (PLS). Lembaga pengumpul data dalam penelitian ini antara lain, Badan Pusat Stastistik Provinsi Riau, Bank Indonesia, literatur-literatur serta informasiinformasi tertulis baik yang berasal dari instansi terkait maupun internet, yang berhubungan dengan topik penelitian untuk memperoleh data sekunder. Penelitian ini dilakukan pada bulan Juli-Agustus 2021.

\section{Jenis Data Penelitian}

Data yang digunakan dalam penelitian ini adalah data kuantitatif dan data kualitatif. Data kuantitatif, yaitu analisis yang dilakukan terhadap data yang diperoleh dari kuesioner terhadap UMKM klaster binaan Bank Indonesia. Sedang data kualitatif, yaitu penulis mengemukakan teori atau konsep mengenai penelitian ini dengan melihat literatur-literatur yang ada baik dari buku maupun jurnal.

\section{Sumber Data Penelitian}

Sumber data yang digunakan dalam penelitian ini adalah data primer dan data sekunder. Data primer yaitu data penelitian yang diperoleh atau dikumpulkan langsung dari objek yang diteliti. Data primer yang dikumpulkan dalam penelitian dilakukan dengan mendistrbusikan angket kepada responden, dimana pertanyaan telah dirancang sesuai dengan variabel yang diteliti. Sedangkan data sekunder adalah data yang bersumber dari catatan yang ada pada perusahaan dan dari sumber lainnya yaitu dengan mengadakan studi kepustakaan.

\section{Variabel Penelitian}

Penelitian ini terdiri dari variabel eksogen, endogen dan intervening. Variabel eksogen dalam penelitian ini adalah orientasi pasar $\left(\mathrm{X}_{1}\right)$, orientasi kewirausahaan $\left(\mathrm{X}_{2}\right)$. Variabel endogen dalam penelitian ini adalah adalah kinerja pemasaran $\left(\mathrm{Y}_{2}\right)$. Variabel intervening dalam penelitian ini adalah inovasi bisnis $\left(\mathrm{Y}_{1}\right)$.

\section{Populasi dan Sampel}

Populasi dalam penelitian ini adalah UMKM Binaan KPW BI Provinsi Riau di wilayah Provinsi Riau yang berjumlah 277 UMKM. Sampel dalam penelitian ini menggunakan teknik sampling cluster sampling dengan terlebih dahulu memasukkan kedalam rumus slovin dan memperoleh sampel berjumlah 164 UMKM dari berbagai klaster.

\section{Teknik Pengumpulan Data}

Metode pengumpulan data primer dilakukan dengan angket/kuesioner. Angket/kuesioner digunakan untuk mendapatkan data dari responden, karena metode yang digunakan dalam penelitian ini adalah dengan survey. metode survey yang dilakukan dengan menggunakan online / electronic questionnaire menggunakan aplikasi google form. Waktu pengisian online / electronic questionnaire diberikan tenggang waktu selama 14 hari. Penyebaran kuesioner dilakukan juga dengan cara membagikan langsung kepada para pengambil keputusan (manajer-owner). Rancangan kuesioner dalam penelitian ini terdiri dari 2 bagian yaitu karakteristik responden dan data pengukuran variabel. Data responden terdiri dari nama, status, jenis kelamin, umur, tingkat pendidikan, lama bekerja.

\section{Teknik Analisis Data}

Metode analisis data yang digunakan dalam penelitian ini adalah analisis jalur. Penelitian ini menggunakan metode analisis data dengan menggunakan software warpPLS versi 3.0 yang dijalankan dengan media komputer. PLS (Partial Least Square) merupakan analisis persamaan jalur. PLS adalah metode analisis yang bersifat soft modeling karena tidak mengasumsikan data 
harus dengan pengukuran skala tertentu, yang berarti jumlah sampel dapat kecil atau dibawah 100 sampel.

\section{Hasil dan Pembahasan}

\section{Distribusi Responden berdasarkan Lama Mendirikan Usaha}

Tabel 1. Distribusi Responden Berdasarkan Lama Mendirikan Usaha

\begin{tabular}{lcc}
\hline $\begin{array}{c}\text { Lama } \\
\text { Mendirikan } \\
\text { Usaha }\end{array}$ & Jumlah & $\begin{array}{c}\text { Persentase } \\
(\%)\end{array}$ \\
\hline$<1$ Tahun & 29 & 17,68 \\
1-3 Tahun & 73 & 44,51 \\
3-5 Tahun & 39 & 23,78 \\
$>$ 5-10 Tahun & 23 & 14,02 \\
\hline Jumlah & 164 & 100,00 \\
\hline
\end{tabular}

Sumber: Data Primer, diolah (2021)

Pada tabel 1 diketahui dari 164 UMKM pada klaster Binaan Bank Indonesia Provinsi Riau, dikelompokkan berdasarkan lama mendirikan usaha. Untuk responden yang waktu mendirikan usahanya $<1$ tahun berjumlah sebanyak 29 responden atau sebesar (17,68\%), responden yang waktu mendirikan usaha 1-3 tahun berjumlah 73 responden atau sebesar (44,51\%). Responden yang waktu mendirikan usaha 3-5 tahun berjumlah 39 responden atau sebesar $(23,78 \%)$, kemudian responden yang waktu mendirikan usaha $>5-10$ tahun berjulmah 23 responden atau sebesar $(14,02 \%)$. Dengan begitu bisa diketahui secara proporsional mayoritas responden tergolong kedalam responden dengan lama mendirikan usaha 1-3 tahun yaitu berjumlah 73 responden dengan persentase sebesar $44,51 \%$, sedangkan responden dengan persentase terkecil yaitu $14,02 \%$ tergolong kedalam responden dengan lama mendirikan usaha $>5-10$ tahun yang berjumlah sebanyak 23 responden.

\section{Distribusi Responden Berdasarkan Status Kepemilikan}

Tabel 2. Distribusi Responden Berdasarkan Status Kepemilikan

\begin{tabular}{lcc}
\hline \multicolumn{1}{c}{ Status Kepemilikan } & Jumlah & $\begin{array}{c}\text { Persentase } \\
(\%)\end{array}$ \\
\hline Pemilik UMKM & 74 & 45,12 \\
Manajer UMKM & 46 & 28,05 \\
Karyawan/Staf & 32 & 19,51 \\
Distributor/Reseller & 12 & 7,32 \\
\hline Jumlah & 164 & 100,00 \\
\hline Sumber: Data Primer, diolah (2021) &
\end{tabular}

Pada tabel 2 diketahui bahwa responden paling banyak tergolong kedalam kategori pemilik UMKM dengan jumlah sebanyak 74 responden atau sebesar $(45,12 \%)$. Kategori manajer UMKM sebanyak 46 responden ataupun sebesar (28,05\%). Responden paling sedikit berada pada kategori karyawan/staf yaitu sebanyak 32 responden atau sebesar (19,51\%). Sedangkan untuk distributor/reseller sebanyak 12 responden atau sebesar $(7,32 \%)$.

\section{Distribusi Responden Berdasarkan Lokasi Tempat Usaha}

Tabel 3. Distribusi Responden Berdasarkan Lokasi Tempat Usaha

\begin{tabular}{|c|c|c|c|}
\hline $\begin{array}{l}\text { Lokasi } \\
\text { Usaha }\end{array}$ & Tempat & Jumlah & $\begin{array}{l}\text { Persentase } \\
(\%)\end{array}$ \\
\hline Pekanbaru & & 63 & 38,41 \\
\hline Siak & & 77 & 46,95 \\
\hline Meranti & & 24 & 14,63 \\
\hline Jumlah & & 164 & 100,00 \\
\hline
\end{tabular}

Pada tabel 3 diketahui bahwa responden paling banyak memiliki lokasi tempat usaha di siak yaitu berjumlah 77 responden atau sebesar (46,95\%), responden yang memiliki lokasi usaha di Pekanbaru berjumlah sebanyak 63 responden atau sebesar $(38,41 \%)$, sedangkan responden paling sedikit memiliki lokasi usaha di Meranti dengan jumlah sebanyak 24 responden atau sebesar $(14,63 \%)$. 


\section{Uji Validitas Konvergen dan Diskriminan}

Validitas merupakan ukuran yang menentukan tingkatan kevalidan suatu instrumen. Suatu instrumen dapat dikatakan valid jika dapat menentukan apa yang diperlukan atau bisa memperkirakan data dari variabel yang diteliti dengan benar. apabila nilai koefisien korelasi (loadings factor) lebih besar dari 0,50 hingga 0,60 maka telah mencapai kriteria validtas konvergen, sedangkan apabila hasil koefisien korelasi (loadings factor) $>$ hasil cross loading bisa dinyatakan memenuhi kriteria validitas diskriminan.

Tabel 4. Validitas Konvergen dan Diskriminan Variabel Orientasi Pasar

\begin{tabular}{lllllll}
\hline Item & Orientasi Pasar & $\begin{array}{l}\text { Orientasi } \\
\text { Kewirausahaan }\end{array}$ & Inovasi Bisnis & $\begin{array}{l}\text { Kinerja } \\
\text { Pemasaran }\end{array}$ & SE & P value \\
\hline $\mathrm{X} 1.1$ & 0.765 & -0.077 & 0.159 & 0.115 & 0.080 & $<0.001$ \\
$\mathrm{X} 1.2$ & 0.838 & 0.009 & -0.159 & -0.022 & 0.069 & $<0.001$ \\
$\mathrm{X} 1.3$ & 0.869 & 0.059 & 0.013 & -0.08 & 0.062 & $<0.001$ \\
\hline
\end{tabular}

Sumber: Data diolah, (2021)

Tabel 4 memperlihatkan nilai loadings factor dari seluruh indikator orientasi pasar memiliki nilai loadings factor $>0.6$; yaitu 0,$765 ; 0,838$; dan 0,869 dengan p-value $<0.001$. hasil tersebut dapat dijelaskan bahwa seluruh item orientasi pasar sudah terpenuhi kriteria validitas konvergen. Dari hasil yang diperoleh menunjukkan bahwa indikator X1.1 memiliki nilai loading factor 0.765 lebih besar dari pada $-0,077$; 0,159; dan 0,115. Seluruh indikator pada variabel orientasi pasar juga memenuhi kriteria validitas diskriminan karena memiliki nilai loadings factor $>$ cross loadings.

Tabel 5. Validitas Konvergen dan Diskriminan Variabel Orientasi Kewirausahaan

\begin{tabular}{cllllll}
\hline Item & Orientasi Pasar & \multicolumn{1}{c}{$\begin{array}{c}\text { Orientasi } \\
\text { Kewirausahaan }\end{array}$} & Inovasi Bisnis & $\begin{array}{c}\text { Kinerja } \\
\text { Pemasaran }\end{array}$ & SE & P value \\
\hline X2.1 & -0.101 & 0.756 & -0.141 & 0.002 & 0.076 & $<0.001$ \\
X2.2 & -0.103 & 0.840 & -0.172 & 0.112 & 0.054 & $<0.001$ \\
X2.3 & 0.098 & 0.885 & -0.052 & -0.101 & 0.054 & $<0.001$ \\
X2.4 & 0.006 & 0.851 & 0.058 & 0.076 & 0.058 & $<0.001$ \\
X2.5 & 0.119 & 0.602 & 0.411 & -0.119 & 0.102 & $<0.001$ \\
\hline
\end{tabular}

Sumber: Data Primer (combined loading and cross loading), diolah (2021)

Tabel 5 memperlihatkan nilai loadings factor dari seluruh indikator orientasi kewirausahaan mempunyai nilai loadings factor yang lebih besar dari $0,6(>0,6)$; yaitu 0,$756 ; 0,840 ; 0,885 ; 0,851$ dan 0,602 dengan p-value $<0.001$. Hasil ini menyatakan bahwa seluruh item orientasi pasar memenuhi kriteria validitas konvergen. Seluruh indikator indikator pada variabel orientasi kewirausahaan juga memenuhi kriteria validitas diskriminan dikarenakan memiliki nilai loadings factor $>$ cross loadings.

Tabel 6. Validitas Konvergen dan Diskriminan Variabel Inovasi Bisnis

\begin{tabular}{cllllll}
\hline Item & $\begin{array}{c}\text { Orientasi } \\
\text { Pasar }\end{array}$ & \multicolumn{1}{c}{$\begin{array}{c}\text { Orientasi } \\
\text { Kewirausahaan }\end{array}$} & Inovasi Bisnis & $\begin{array}{c}\text { Kinerja } \\
\text { Pemasaran }\end{array}$ & SE & P value \\
\hline Z.1 & -0.053 & 0.135 & 0.781 & -0.086 & 0.079 & $<0.001$ \\
Z.2 & 0.056 & 0.182 & 0.844 & -0.056 & 0.080 & $<0.001$ \\
Z.3 & -0.008 & -0.313 & 0.828 & 0.138 & 0.068 & $<0.001$ \\
\hline
\end{tabular}

Sumber: Data Olahan 2021

Tabel 6 menjelaskan nilai loadings factor dari seluruh indikator orientasi kewirausahaan mempunyai nilai loadings factor yang lebih besar dari $0,6(>0,6)$; yaitu 0,$781 ; 0,844$; dan 0,828 
dengan p-value $<0.001$. Menyatakan bahwa seluruh indikator Inovasi bisnis memenuhi kriteria validitas konvergen, kemudian seluruh indikator pada variabel tersebut juga memenuhi kriteria validitas diskriminan dikarenakan memiliki nilai loadings factor $>$ cross loadings.

Tabel 7. Validitas Konvergen dan Diskriminan Variabel Kinerja Pemasaran

\begin{tabular}{lllllll}
\hline Item & $\begin{array}{c}\text { Orientasi } \\
\text { Pasar }\end{array}$ & \multicolumn{1}{c}{$\begin{array}{c}\text { Orientasi } \\
\text { Kewirausahaan }\end{array}$} & Inovasi Bisnis & $\begin{array}{c}\text { Kinerja } \\
\text { Pemasaran }\end{array}$ & SE & P value \\
\hline Y.1 & -0.273 & -0.293 & 0.137 & 0.699 & 0.154 & $<0.001$ \\
Y.2 & -0.019 & 0.104 & 0.078 & 0.827 & 0.079 & $<0.001$ \\
Y.3 & 0.267 & 0.154 & -0.207 & 0.776 & 0.113 & $<0.001$ \\
\hline
\end{tabular}

Sumber: Data Olaban 2021

Tabel 7 menjelaskan nilai loadings factor dari seluruh indikator kinerja pemasaran mempunyai nilai loadings factor yang lebih besar dari $0,6(>0,6)$; yaitu 0,$699 ; 0,827$; dan 0,776 dengan $p$-value $<0.001$. Hasil ini menjelaskan bahwa seluruh item orientasi pasar memenuhi kriteria validitas konvergen. Seluruh indikator indikator pada variabel kinerja pemasaran juga memenuhi kriteria validitas diskriminan karena memiliki nilai loadings factor $>$ cross loadings.

\section{Uji Reliabilitas}

Reliabilitas dipergunakan dalam melihat tingkat kecocokan dari setiap variabel yang dipergunakan pada penelitian tersebut. Reliabilitas setiap indikator bisa tampak dari reliabilitas komposit ataupun melalui croncbach's alpha.

Tabel 8. Penilaian Reliabilitas

\begin{tabular}{|c|c|}
\hline Nilai r & Keterangan \\
\hline$r>0.90$ & Sangat Tinggi \\
\hline$r>0.80$ & Tinggi \\
\hline$r>0.70$ & Cukup \\
\hline$r>0.60$ & Sedang \\
\hline$r>0.50$ & Rendah \\
\hline$r>0.40$ & Sangat rendah \\
\hline
\end{tabular}

Menurut rentang nilai di atas, hasil pengujian reliabilitas pada instrumen penelitian disajikan pada tabel 9 berikut:

Tabel 9. Hasil Perhitungan Reliabilitas

\begin{tabular}{lllll}
\hline \multicolumn{1}{c}{ Reliability } & Orientasi Pasar & $\begin{array}{c}\text { Orientasi } \\
\text { Kewirausahaan }\end{array}$ & Inovasi Bisnis & $\begin{array}{c}\text { Kinerja } \\
\text { Pemasaran }\end{array}$ \\
\hline Composite reliability & 0.864 & 0.893 & 0.858 & 0.812 \\
Kategori & Tinggi & Tinggi & Tinggi & Tinggi \\
Cronbach's alpha & 0.764 & 0.848 & 0.752 & 0.652 \\
Kategori & Cukup & Tinggi & Cukup & Sedang \\
\hline
\end{tabular}

Sumber: Data Primer, diolah (2021)

Pabel Tabel 9 nilai reliabilitas komposit nilai reliabilitas variabel orientasi pasar adalah sebesar 0.864 termasuk kedalam kategori tinggi kemudian nilai cronbach's alpha sebesar 0,764 pada kategori cukup, nilai reliabilitas komposit variabel orientasi kewirausahaan adalah 0.893 juga termasuk kategori reliabilitas tinggi dengan nilai cronbach's alpha sebesar 0,848 dalam kategori tinggi. Selanjutnya variabel Inovasi bisnis sebesar 0,858 juga dalam kategori tinggi dengan nilai cronbach's alpha sebesar 0.752 dengam kategori cukup. Selanjutnya adalah yang terakhir variabel kinerja pemasaran memiliki nilai reliabilitas komposit sebesat 0,812 , tentunya juga dalam kategori tinggi dengan cronbach's alpha sebesar 0,652 dengan kategori cukup.

\section{Variabel Orientasi Pasar (X1)}

Tabel 10. Statistik Deskriptif Variabel Orientasi Pasar (X1)

\begin{tabular}{|l|l|l|}
\hline Variabel & Keterangan & Hasil Statistik \\
\hline \multirow{4}{*}{ Orientasi Pasar } & N & 164 \\
\cline { 2 - 3 } & Mean & 3,06 \\
\cline { 2 - 3 } & Median & 3,00 \\
\hline
\end{tabular}




\begin{tabular}{|l|l|l|}
\hline Variabel & Keterangan & Hasil Statistik \\
\hline \multirow{7}{*}{} & Mode & 3,00 \\
\cline { 2 - 3 } & Range & 1,92 \\
\cline { 2 - 3 } & Minimum & 2,23 \\
\cline { 2 - 3 } & Maximum & 4,15 \\
\hline
\end{tabular}

Sumber: Data Olaban 2021

Tabel 10 menjelaskan bahwa orientasi pasar terdiri dari 3 indikator didapatkan nilai mean yang adalah nilai dari rata-rata semua data orientasi pasar sebesar 3,06, nilai tengah (median) dari orientasi pasar sebesar 3,00 dan nilai yang sering muncul (modus) dari orientasi pasar sebesar 3,00.

Tabel 11. Deskripsi Frekuensi Variabel Orientasi Pasar (X1)

\begin{tabular}{|c|c|c|c|c|}
\hline Interva & & Kategori & Frekuensi & $\begin{array}{c}\text { Persentase } \\
(\%)\end{array}$ \\
\hline $\begin{array}{l}4,21 \\
5,00\end{array}$ & & $\begin{array}{l}\text { Sangat } \\
\text { Tinggi }\end{array}$ & 0 & 0,00 \\
\hline $\begin{array}{l}3,21 \\
4,20\end{array}$ & - & Tinggi & 49 & 29,88 \\
\hline $\begin{array}{l}2,61 \\
3,20\end{array}$ & - & Sedang & 105 & 64,02 \\
\hline $\begin{array}{l}1,81 \\
2,60\end{array}$ & - & Rendah & 10 & 6,10 \\
\hline $\begin{array}{l}1,00 \\
1,80\end{array}$ & - & $\begin{array}{l}\text { Sangat } \\
\text { Rendah }\end{array}$ & 0 & 0 \\
\hline Jumlah & & & 164 & 100 \\
\hline
\end{tabular}

Tabel 11 responden yang tergolong kedalam kategori tinggi sebanyak 49 responden atau sebesar 29,88\%, responden yang tergolong kedalam kategori sedang sebanyak 105 responden atau sebesar 64,02\%, responden yang tergolong kedalam kategori rendah sebanyak 10 responden atau sebesar 6,10\%. Dapat diambil kesimpulan bahwa variabel orientasi pasar tergolong dalam kategori tinggi.

Tabel 12. Nilai Mean Variabel Orientasi Pasar Berdasarkan Masing-Masing Indikator

\begin{tabular}{llll}
\hline No & Indikator & Mean & Tafsiran \\
\hline 1 & Orientasi Pelanggan & 2,81 & Sedang \\
2 & Orientasi Pesaing & 3,33 & Tinggi \\
3 & Koordinasi & 3,05 & Sedang \\
\hline Interfungsional & & \\
\hline Rata-Rata & 3,06 & Sedang \\
\hline
\end{tabular}

Sumber: Data Olaban 2021

Tabel 12 nilai mean pada variabel orientasi pasar dijelaskan berdasarkan masing-masing indikator. Nilai mean pada indikator variabel orientasi pasar paling tinggi adalah orientasi pesaing dengan nilai mean sebesar 3,33, diikuti koordinasi interfungsional nilai mean sebesar 3,05 , kemudian orientasi pelanggan nilai mean sebesar 2,81.

\section{Variabel Orientasi Kewirausahaan $\left(\mathbf{X}_{2}\right)$}

Tabel 13. Statistik Deskriptif Variabel Orientasi Kewirausahaan (X2)

\begin{tabular}{|l|l|c|}
\hline \multirow{4}{*}{ Variabel } & Keterangan & $\begin{array}{c}\text { Hasil } \\
\text { Statistik }\end{array}$ \\
\hline \multirow{4}{*}{$\begin{array}{l}\text { Orientasi } \\
\text { Kewirausahaan }\end{array}$} & N & 164 \\
\cline { 2 - 3 } & Mean & 3,14 \\
\cline { 2 - 3 } & Median & 3,14 \\
\cline { 2 - 3 } & Mode & 3,00 \\
\cline { 2 - 3 } & Range & 2,22 \\
\cline { 2 - 3 } & Minimum & 2,14 \\
\cline { 2 - 3 } & Maximum & 4,36 \\
\hline \multirow{2}{*}{ Sumber: Data Olahan 2021 }
\end{tabular}

Nilai mean yang diperoleh yaitu sebesar 3,14, nilai median yang diperoleh sebesar 3,14 dan nilai modus yang diperoleh sebesar 3,00. Untuk nilai maximum yang diperoleh sebesar 4,36 dan untuk nilai minimum yang diperoleh sebesar 2,14 . Dengan demikian nilai untuk variabel orientasi kewirausahaan dalam kategori tinggi.

Tabel 14. Deskripsi Frekuensi Orientasi Kewirausahaan (X2)

\begin{tabular}{|c|c|c|c|c|}
\hline Interva & & Kategori & Frekuensi & $\begin{array}{c}\text { Persentase } \\
(\%)\end{array}$ \\
\hline $\begin{array}{l}4,21 \\
5,00\end{array}$ & - & $\begin{array}{l}\text { Sangat } \\
\text { Tinggi }\end{array}$ & 3 & 1,83 \\
\hline $\begin{array}{l}3,21 \\
4,20\end{array}$ & - & Tinggi & 76 & 46,34 \\
\hline $\begin{array}{l}2,61 \\
3,20\end{array}$ & - & Sedang & 62 & 37,80 \\
\hline $\begin{array}{l}1,81 \\
2,60\end{array}$ & - & Rendah & 23 & 14,02 \\
\hline $\begin{array}{l}1,00 \\
1,80 \\
\end{array}$ & - & $\begin{array}{l}\text { Sangat } \\
\text { Rendah }\end{array}$ & 0 & 0 \\
\hline Jumlah & & & 164 & 100 \\
\hline
\end{tabular}

Sumber: Data Olahan 2021

Tabel 14 diketahui adanya responden yang tergolong kedalam kategori sangat tinggi adalah sebanyak 3 responden atau sebesar 1,83\%, kemudian responden yang tergolong kedalam kategori tinggi adalah sebanyak 76 responden atau sebesar $46,34 \%$, kemudian responden yang tergolong kedalam kategori sedang adalah 
sebanyak 62 responden atau sebesar 37,80\%, sedangkan responden yang tergolong kedalam kategori rendah adalah sebanyak 23 responden atau sebesar 14,02\%. Dengan begitu bisa diambil kesimpulan bahwa variabel orientasi kewirausahaan tergolong dalam kategori sedang.

Tabel 15. Nilai Mean Variabel Orientasi Kewirausahaan Berdasarkan Masing-Masing Indikator

\begin{tabular}{llll}
\hline No & Indikator & Mean & Tafsiran \\
\hline 1 & Innovativeness & 3,17 & Sedang \\
2 & Pengambilan Resiko & 3,29 & Tinggi \\
3 & Proaktif & 3,29 & Tinggi \\
4 & Sikap Agresif & 3,21 & Sedang \\
5 & Otonomi & 2,76 & Sedang \\
\hline Rata-Rata & 3,14 & Sedang \\
\hline Sumber: Data Olaban 2021 & &
\end{tabular}

Tabel 15 menjelaskan tentang nilai mean pada variabel orientasi kewirausahaan yang dijelaskan berdasarkan masing-masing indikator. Nilai mean paling tinggi adalah pengambilan resiko dan proaktif dengan masing-masing nilai mean sebesar 3,29 dan 3,29, diikuti sikap agresif 3,21 dengan nilai mean sebesar 3,21, kemudian innovativeness dengan nilai mean sebesar 3,17, sedangkan indikator otonomi memperoleh nilai mean sebesar 2,76.

\section{Variabel Inovasi Bisnis $\left(\mathbf{Y}_{1}\right)$}

Tabel 16. Statistik Deskriptif Variabel Inovasi Bisnis (Y1)

\begin{tabular}{|l|l|l|}
\hline Variabel & Keterangan & Hasil Statistik \\
\hline \multirow{5}{*}{ Inovasi Bisnis } & N & 164 \\
\cline { 2 - 3 } & Mean & 3,18 \\
\cline { 2 - 3 } & Median & 3,22 \\
\cline { 2 - 3 } & Mode & 3,22 \\
\cline { 2 - 3 } & Range & 2,67 \\
\cline { 2 - 3 } & Minimum & 2,11 \\
\cline { 2 - 3 } & Maximum & 4,78 \\
\hline
\end{tabular}

Sumber: Data Olahan 2021

Nilai mean yang diperoleh dari data variabel inovasi bisnis yaitu sebesar 3,18 , nilai median yang diperoleh sebesar 3,22 dan nilai modus yang diperoleh sebesar 3,22. Untuk nilai maximum yang diperoleh sebesar 4,78 dan untuk nilai minimum yang diperoleh sebesar 2,11. Dengan demikian nilai untuk variabel inovasi bisnis dalam kategori sedang.
Tabel 17. Deskripsi Frekuensi Inovasi Bisnis (Y1)

\begin{tabular}{|c|c|c|c|c|}
\hline Interva & & Kategori & Frekuensi & $\begin{array}{c}\text { Persentase } \\
(\%)\end{array}$ \\
\hline $\begin{array}{l}4,21 \\
5,00\end{array}$ & & $\begin{array}{l}\text { Sangat } \\
\text { Tinggi }\end{array}$ & 5 & 3,05 \\
\hline $\begin{array}{l}3,21 \\
4,20\end{array}$ & - & Tinggi & 78 & 47,56 \\
\hline $\begin{array}{l}2,61 \\
3,20\end{array}$ & - & Sedang & 59 & 35,98 \\
\hline $\begin{array}{l}1,81 \\
2,60\end{array}$ & - & Rendah & 22 & 13,41 \\
\hline $\begin{array}{l}1,00 \\
1,80\end{array}$ & - & $\begin{array}{l}\text { Sangat } \\
\text { Rendah }\end{array}$ & 0 & 0 \\
\hline Jumlah & & & 164 & 100 \\
\hline
\end{tabular}

Tabel 17 dinyatakan bahwa responden yang tergolong kedalam kategori sangat tinggi sebanyak 5 responden atau sebesar 3,05\%, kemudian responden yang tergolong kedalam kategori tinggi sebanyak 78 responden atau sebesar 47,56\%, kemudian responden yang tergolong kedalam kategori sedang sebanyak 59 responden atau sebesar 35,98\%, sedangkan responden yang tergolong kedalam kategori rendah sebanyak 22 responden atau sebesar 13,41\%. Dengan demikian disimpulkan bahwa variabel inovasi bisnis tergolong dalam kategori sedang.

Tabel 18. Nilai Mean Variabel Inovasi Bisnis Berdasarkan Masing-Masing Indikator

\begin{tabular}{llll}
\hline No & Indikator & Mean & Tafsiran \\
\hline 1 & Inovasi Produk & 3,27 & Tinggi \\
2 & Inovasi Proses & 3,09 & Sedang \\
3 & Inovasi Distribusi & 3,19 & Sedang \\
\hline Rata-Rata & 3,18 & Sedang \\
\hline Sumber: Data Olaban 2021 & &
\end{tabular}

Tabel 18 menjelaskan nilai mean pada variabel inovasi bisnis berdasarkan masing-masing indikator. Nilai mean pada indikator variabel inovasi bisnis paling tinggi adalah inovasi produk dengan nilai mean sebesar 3,27, diikuti inovasi distribusi dengan nilai mean sebesar 3,19, sedangkan indikator inovasi proses memperoleh nilai mean sebesar 3,09. 


\section{Variabel Kinerja Pemasaran $\left(\mathrm{Y}_{2}\right)$}

Tabel 19. Statistik Deskriptif Variabel Kinerja Pemasaran (Y2)

\begin{tabular}{|l|l|l|}
\hline Variabel & Keterangan & $\begin{array}{l}\text { Hasil } \\
\text { Statistik }\end{array}$ \\
\hline \multirow{5}{*}{ Kinerja Pemasaran } & N & 164 \\
\cline { 2 - 3 } & Mean & 3,46 \\
\cline { 2 - 3 } & Median & 3,50 \\
\cline { 2 - 3 } & Mode & 3,17 \\
\cline { 2 - 3 } & Range & 2,34 \\
\cline { 2 - 3 } & Minimum & 2,33 \\
\cline { 2 - 3 } & Maximum & 4,67 \\
\hline
\end{tabular}

Sumber: Data Olahan 2021

Nilai mean diperoleh dari data variabel kinerja pemasaran yaitu sebesar 3,46, nilai median yang diperoleh sebesar 3,50 dan nilai modus yang diperoleh sebesar 3,17. Untuk nilai maximum yang diperoleh sebesar 4,67 dan untuk nilai minimum yang diperoleh sebesar 2,33. Dengan demikian nilai untuk variabel kinerja pemasaran dalam kategori tinggi.

Tabel 20. Deskripsi Frekuensi Kinerja Pemasaran (X2)

\begin{tabular}{|c|c|c|c|c|}
\hline Interval & & Kategori & Frekuensi & $\begin{array}{l}\text { Persentase } \\
(\%)\end{array}$ \\
\hline $\begin{array}{l}4,21 \\
5,00\end{array}$ & - & $\begin{array}{l}\text { Sangat } \\
\text { Tinggi }\end{array}$ & 8 & 4,88 \\
\hline $\begin{array}{l}3,21 \\
4,20\end{array}$ & - & Tinggi & 103 & 62,80 \\
\hline $\begin{array}{l}2,61 \\
3,20\end{array}$ & - & Sedang & 48 & 29,27 \\
\hline $\begin{array}{l}1,81 \\
2,60\end{array}$ & - & Rendah & 5 & 3,05 \\
\hline $\begin{array}{l}1,00 \\
1,80\end{array}$ & - & $\begin{array}{l}\text { Sangat } \\
\text { Rendah }\end{array}$ & 0 & 0 \\
\hline Jumlah & & & 164 & 100 \\
\hline
\end{tabular}

Tabel 20 dinyatakan bahwa responden yang tergolong kedalam kategori sangat tinggi sebanyak 8 responden atau sebesar 4,88\%, responden yang tergolong kedalam kategori tinggi sebanyak 103 responden atau sebesar $62,80 \%$, responden yang tergolong kedalam kategori sedang sebanyak 48 responden atau sebesar $29,27 \%$, responden yang tergolong kedalam kategori rendah sebanyak 5 responden atau sebesar 3,05\%. Dengan begitu dapat diambil kesimpulan bahwa variabel kinerja pemasaran tergolong dalam kategori tinggi.
Tabel 21. Nilai Mean Variabel Kinerja

Pemasaran Berdasarkan Masing-Masing Indikator

\begin{tabular}{llll}
\hline No & Indikator & Mean & Tafsiran \\
\hline 1 & Pertumbuhan Penjualan & 3,89 & Tinggi \\
2 & Pertumbuhan Pelanggan & 3,31 & Tinggi \\
3 & Pangsa Pasar & 3,20 & Sedang \\
Rata-Rata & 3,46 & Sedang \\
\hline Sumber: Data Olaban 2021 &
\end{tabular}

Tabel 21 menjelaskan tentang nilai mean pada variabel kinerja pemasaran yang berdasarkan masing-masing indikator. Nilai mean pada indikator kinerja pemasaran paling tinggi adalah pertumbuhan penjualan dengan nilai mean sebesar 3,89, diikuti pertumbuhan pelanggan dengan nilai mean sebesar 3,31, sedangkan pangsa pasar memperoleh nilai mean sebesar 3,20 .

\section{Analisis SEM-PLS Outer Model}

Tabel 22. Analisis Outer Model Fit

\begin{tabular}{lll}
\hline Model & Fit Indices & $P$ V alues \\
\hline APC & 0.326 & $\mathrm{P}<0.001$ \\
ARS & 0.517 & $\mathrm{P}<0.001$ \\
AVIF & 1.688 & Good if $<5$ \\
\hline Sumber: Data Olahon 2021 &
\end{tabular}

Sumber: Data Olahan 2021

Tabel 22 memperlihatkan adanya indikator model fit dengan APC 0.326, ARS 0.517 \& P value $<0.001$ dikatakan signifikan dikarenakan telah terpenuhi nilai signifikannya yaitu 0,05 . Sedangkan AVIF sebesar 1.688 terpenuhi syarat kurang dari 5, pengujian data penelitian menggunakan model fit serta dinyatakan data penelitian fit menghasilkan data penelitian ini tidak terjadi multikolirearitas.

\section{Average Variance External}

Tabel 23. Analisis Average Variance Extracted (AVE)

\begin{tabular}{llll}
\hline $\begin{array}{c}\text { Orientasi } \\
\text { Pasar }\end{array}$ & $\begin{array}{c}\text { Orientasi } \\
\text { Kewirausahaan }\end{array}$ & $\begin{array}{c}\text { Inovasi } \\
\text { Bisnis }\end{array}$ & $\begin{array}{c}\text { Kinerja } \\
\text { Pemasaran }\end{array}$ \\
\hline 0.681 & 0.630 & 0.669 & 0.592 \\
\hline Sumber: Data Olahan 2021 & &
\end{tabular}

Tabel 23 mengungkapkan bahwa AVE bisa dipakai dalam memperkirakan berapa banyak varians di dalam kostruk dibandingkan oleh variansi yang ditimbulkan pada pengukuran. 
Hasil pengujian AVE pada penelitian ini dalam variabel orientasi pasar sebesar 0,681 orientasi kewirausahaan sebesar 0,630 Inovasi bisnis sebesar 0,669 serta kinerja pemasaran sebesar 0,592 . Nilai AVE dalam semua variabel telah melebihi 0,5, sehingga bisa dikatakan telah memenuhi standar berdasarkan nilai AVE.

\section{Inner Model}

Pada hipotesisi ini tingkat signifikansi pengujian dilakukan berdasarkan pada nilai p-value.

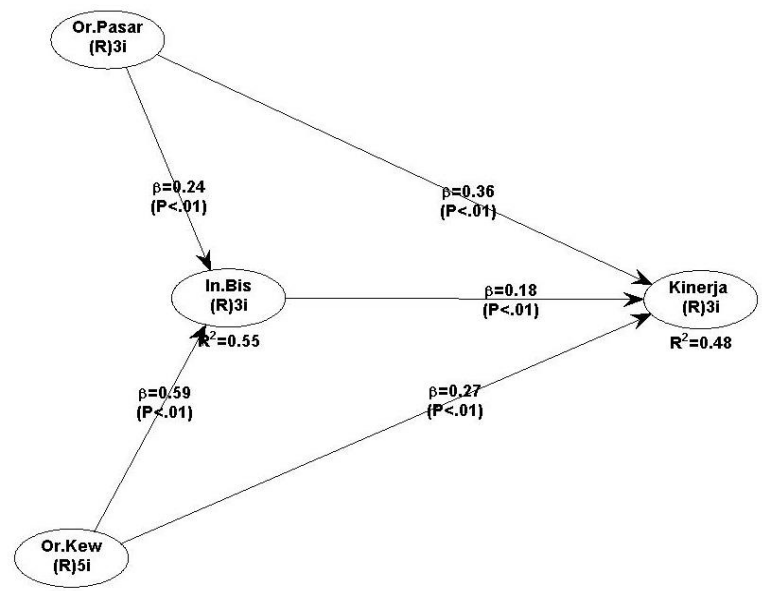

Gambar 1. Persamaan Struktural

Gambar 1 menyatakan hasil koefisien jalur menggunakan tingkat signifikansi sama dengan perhitungan yang sudah dilakukan menggunakan Warp PLS

Tabel 24. Analisis Path coefficient and $p$ values

\begin{tabular}{|c|c|c|c|c|c|}
\hline \multicolumn{2}{|c|}{$\begin{array}{l}\text { Hubungan antar } \\
\text { variabel }\end{array}$} & \multicolumn{2}{|c|}{$\begin{array}{c}\text { Path } \\
\text { Coefficient }\end{array}$} & \multicolumn{2}{|c|}{$\begin{array}{c}\text { Tingkat } \\
\text { Signifikansi }\end{array}$} \\
\hline Eksogen & $\begin{array}{l}\text { Endog } \\
\text { en }\end{array}$ & $\begin{array}{l}\text { Coef } \\
f .\end{array}$ & $\begin{array}{l}P \text { - } \\
\text { value }\end{array}$ & value & Ket. \\
\hline $\begin{array}{l}\text { Orientasi } \\
\text { Pasar } \\
\left(\mathrm{X}_{1}\right)\end{array}$ & $\begin{array}{l}\text { Inovasi } \\
\text { Bisnis } \\
\left(\mathrm{Y}_{1}\right) \\
\end{array}$ & $\begin{array}{l}0.2 \\
38\end{array}$ & $\begin{array}{l}0.00 \\
1\end{array}$ & $\begin{array}{l}\mathrm{P}<0.0 \\
1\end{array}$ & $\begin{array}{l}\text { Signifik } \\
\text { an } \\
\text { Tinggi } \\
\end{array}$ \\
\hline $\begin{array}{l}\text { Orientasi } \\
\text { Kewirausa } \\
\text { haan }\left(\mathrm{X}_{2}\right)\end{array}$ & $\begin{array}{l}\text { Inovasi } \\
\text { Bisnis } \\
\left(\mathrm{Y}_{1}\right)\end{array}$ & $\begin{array}{l}0.5 \\
86\end{array}$ & $\begin{array}{l}<0.0 \\
01\end{array}$ & $\begin{array}{l}\mathrm{P}<0.0 \\
1\end{array}$ & $\begin{array}{l}\text { Signifik } \\
\text { an } \\
\text { Tinggi }\end{array}$ \\
\hline $\begin{array}{l}\text { Orientasi } \\
\text { Pasar } \\
\left(\mathrm{X}_{1}\right)\end{array}$ & $\begin{array}{l}\text { Kinerja } \\
\text { Pemasa } \\
\text { ran } \\
\left(\mathrm{Y}_{2}\right)\end{array}$ & $\begin{array}{l}0.3 \\
60\end{array}$ & $\begin{array}{l}<0.0 \\
01\end{array}$ & $\begin{array}{l}\mathrm{P}<0.0 \\
1\end{array}$ & $\begin{array}{l}\text { Signifik } \\
\text { an } \\
\text { Tinggi }\end{array}$ \\
\hline $\begin{array}{l}\text { Orientasi } \\
\text { Kewirausa } \\
\text { baan }\left(\mathrm{X}_{2}\right)\end{array}$ & $\begin{array}{l}\text { Kinerja } \\
\text { Pemasa } \\
\text { ran } \\
\left(\mathrm{Y}_{2}\right)\end{array}$ & $\begin{array}{l}0.2 \\
71\end{array}$ & 0.01 & $\begin{array}{l}\mathrm{P}<0.0 \\
1\end{array}$ & $\begin{array}{l}\text { Signifik } \\
\text { an } \\
\text { Tinggi }\end{array}$ \\
\hline $\begin{array}{l}\text { Inovasi } \\
\text { Bisnis } \\
\left(\mathrm{Y}_{1}\right)\end{array}$ & $\begin{array}{l}\text { Kinerja } \\
\text { Pemasa } \\
\text { ran } \\
\left(\mathrm{Y}_{2}\right)\end{array}$ & $\begin{array}{l}0.1 \\
77\end{array}$ & $\begin{array}{l}0.00 \\
9\end{array}$ & $\begin{array}{l}\mathrm{P}<0.0 \\
1\end{array}$ & $\begin{array}{l}\text { Signifik } \\
\text { an } \\
\text { Tinggi }\end{array}$ \\
\hline
\end{tabular}

\begin{tabular}{|c|c|c|c|c|c|}
\hline \multicolumn{2}{|c|}{$\begin{array}{l}\text { Hubungan antar } \\
\text { variabel }\end{array}$} & \multicolumn{2}{|c|}{$\begin{array}{c}\text { Path } \\
\text { Coefficient }\end{array}$} & \multicolumn{2}{|c|}{$\begin{array}{c}\text { Tingkat } \\
\text { Signifikansi }\end{array}$} \\
\hline Eksogen & $\begin{array}{l}\text { Endog } \\
\text { en }\end{array}$ & $\begin{array}{l}\text { Coef } \\
f .\end{array}$ & $\begin{array}{l}P- \\
\text { value }\end{array}$ & value & Ket. \\
\hline $\begin{array}{l}\text { Orientasi } \\
\text { Pasar } \rightarrow \\
\text { Inovasi } \\
\text { Bisnis }\end{array}$ & $\begin{array}{l}\text { Kinerja } \\
\text { Pemasa } \\
\text { ran } \\
\left(\mathrm{Y}_{2}\right) \\
\end{array}$ & $\begin{array}{l}0.0 \\
42\end{array}$ & $\begin{array}{l}0.03 \\
3\end{array}$ & $\begin{array}{l}\mathrm{P}=0.0 \\
33\end{array}$ & $\begin{array}{l}\text { Mamp } \\
\text { u } \\
\text { memed } \\
\text { iasi } \\
\end{array}$ \\
\hline $\begin{array}{l}\text { Orientasi } \\
\text { Kewirausa } \\
\text { haan } \rightarrow \\
\text { Inovasi } \\
\text { Bisnis }\end{array}$ & $\begin{array}{l}\text { Kinerja } \\
\text { Pemasa } \\
\text { ran } \\
\left(\mathrm{Y}_{2}\right)\end{array}$ & $\begin{array}{l}0.1 \\
04\end{array}$ & $\begin{array}{l}0.01 \\
2\end{array}$ & $\begin{array}{l}\mathrm{P}=0.0 \\
12\end{array}$ & $\begin{array}{l}\text { Mamp } \\
\text { u } \\
\text { memed } \\
\text { iasi }\end{array}$ \\
\hline
\end{tabular}

Tabel 24 menunjukkan perhitungan variabel orientasi pasar mempunyai dampak positif serta signifikan kepada variabel Inovasi bisnis, dalam perhitungan ini dihasilkan nilai koefisien jalur 0.238 dengan tingkat signifikansi ataupun $p$-value $<0.01$. Hipotesis orientasi bisnis berpengaruh terhadap Inovasi bisnis (Hipotesis 1) diterima dan hubungannya bersifat positif. Artinya secara langsung orientasi pasar $\left(\mathrm{X}_{1}\right)$ memiliki pengaruh signifikan terhadap Inovasi bisnis $\left(\mathrm{Y}_{1}\right)$.

Variabel orientasi kewirausahaan mempunyai dampak positif serta signifikan kepada Inovasi bisnis. Dalam perhitungan didapatkan nilai koefisien jalur 0.586 dengan tingkat signifikansi atau p-value $<0.001$. Menunjukkan bahwa hipotesis orientasi kewirausahaan berdampak signifikan terhadap Inovasi bisnis (Hipotesis 2) diterima dan hubungannya bersifat positif. Artinya secara langsung orientasi kewirausahaan (X2) berpengaruh signifikan terhadap variabel Inovasi bisnis $\left(\mathrm{Y}_{1}\right)$.

Variabel orientasi pasar berpengaruh positif serta signifikan terhadap kinerja pemasaran, pada perhitungan didapatkan nilai koefisien jalur 0.360 dengan tingkat signifikansi atau $p$ value $<0.01$. Menyatakan bahwa hipotesis orientasi bisnis berpengaruh terhadap kinerja pemasaran (Hipotesis 3) diterima dan hubungannya bersifat positif. Artinya secara langsung orientasi pasar $\left(\mathrm{X}_{1}\right)$ berpengaruh signifikan terhadap kinerja pemasaran $\left(\mathrm{Y}_{2}\right)$.

Variabel orientasi kewirausahaan berpengaruh positif serta signifikan terhadap kinerja pemasaran, dalam perhitungan diperoleh nilai koefisien jalur 0.271 dengan tingkat signifikansi atau p-value $<0.01$. Memperlihatkan bahwa hipotesis orientasi kewirausahaan berpengaruh 
kepada kinerja pemasaran (Hipotesis 4) diterima dan hubungannya bersifat positif. Artinya secara langsung orientasi kewirausahaan $\left(\mathrm{X}_{2}\right)$ berpengaruh signifikan terhadap kinerja pemasaran $\left(\mathrm{Y}_{2}\right)$.

Variabel Inovasi bisnis berpengaruh positif dan signifikan terhadap kinerja pemasaran, dalam perhitungan tersebut diperoleh nilai koefisien jalur 0.177 dengan tingkat signifikansi atau $p$ value 0.009 . Hal ini menjelaskan bahwa hipotesis Inovasi bisnis berpengaruh terhadap kinerja pemasaran (Hipotesis 5) diterima dan hubungannya bersifat positif. Artinya secara langsung Inovasi bisnis $\left(\mathrm{Y}_{1}\right)$ berpengaruh signifikan terhadap kinerja pemasaran $\left(\mathrm{Y}_{2}\right)$.

Variabel orientasi pasar berpengaruh positif serta signifikan terhadap kinerja pemasaran melalui Inovasi bisnis. Perhitungan tersebut didapatkan nilai koefisien jalur 0.042 dengan tingkat signifikansi atau p-value 0.033 . Perhitungan tersebut menjelaskan bahwa hipotesis orientasi pasar berpengaruh signifikan kepada kinerja pemasaran melalui Inovasi bisnis (Hipotesis 6) diterima dan hubungannya bersifat positif. Artinya secara tidak langsung orientasi pasar $\left(\mathrm{X}_{1}\right)$ berpengaruh signifikan terhadap kinerja pemasaran $\left(\mathrm{Y}_{2}\right)$.

Variabel orientasi kewirausahaan mempunyai pengaruh positif serta signifikan kepada kinerja pemasaran melalui Inovasi bisnis. Perhitungan tersebut diperoleh nilai koefisien jalur 0.104 dengan tingkat signifikansi atau p-value 0.012 lebih kecil dari $0.05(<0.05)$. Perhitungan tersebut menjelaskan bahwa hipotesis orientasi kewirausahaan berpengaruh signifikan terhadap kinerja pemasaran melalui Inovasi bisnis (Hipotesis 7) diterima dan hubungannya bersifat positif. Artinya secara tidak langsung orientasi kewirausahaan $\left(\mathrm{X}_{2}\right)$ berpengaruh signifikan terhadap kinerja pemasaran $\left(\mathrm{Y}_{2}\right)$.

\section{Kesimpulan}

1. Orientasi pasar berpengaruh positif signifikan terhadap inovasi bisnis UMKM Binaan KPW Bank Indonesia Provinsi Riau.

2. Orientasi kewirausahaan berpengaruh positif signifikan terhadap inovasi bisnis UMKM Binaan KPW Bank Indonesia Provinsi Riau.
3. Orientasi pasar berpengaruh positif signifikan terhadap peningkatan kinerja pemasaran UMKM Binaan KPW Bank Indonesia Provinsi Riau.

4. Orientasi kewirausahaan berpengaruh positif signifikan tehadap kinerja pemasaran UMKM Binaan KPW Bank Indonesia Provinsi Riau.

5. Inovasi bisnis berpengarug positif signifikan terhadap kinerja pemasaran UMKM Binaan KPW Bank Indonesia Provinsi Riau.

6. Orientasi pasar berpengaruh terhadap kinerja pemasaran melalui inovasi bisnis UMKM Binaan KPW Bank Indonesia Provinsi Riau.

7. Orientasi kewirausahaan berpengaruh positif signifikan terhadap kinerja pemasaran melalui inovasi bisnis UMKM Binaan KPW Bank Indonesia Provinsi Riau.

\section{Daftar Pustaka}

Ahimbisibwe, G. M., Ntayi, J. M., \& Ngoma, M. (2013). Export Market Orientation, Innovation and Performance of Fruit Exporting Firm in Uganda. European Scientific Journal, 9(4), 295-313.

Altuntas, G., Semercioz, F., \& Eregez, H. (2013). Linking strategic and market orientations to organizational performance: the role of innovation in private healthcare organizations. Procedia: Socialn and Behavioral Sciences, 99(9), 413419.

Anggraini, N., Marnis, \& Samsir. (2014). Strategi Orientasi Pasar, Inovasi dan Orientasi Pembelajaran Pengaruhnya Terhadap Kinerja Usaha serta Dampaknya Terhadap Keunggulan Bersaing (Studi pada Jasa Salon Kecantikan dan Spa di Kota Pekanbaru). Jurnal Sosial Ekonomi Pembangunan, 4(12), 295-310.

Asashi, T., \& Sukaatmadja, I. P. G. (2017). Peran inovasi produk dalam memediasi pengaruh orientasi pasar terhadap kinerja pemasaran. E-Jurnal Manajemen Unud, 6(4), 1816-1845. 
Charles, L., Joel, C., \& Samwel, K. C. (2012). Market Orientation and Firm Performance in The Manufacturing Sector in Kenya. European Journal of Business and Management, 4(10), 20-27.

Ejdys, J. (2015). Entrepreneurial Orientation vs Innovativeness of Small and Medium Size Enterprises. Journal of Engineering, Project, and Production Management, 6(1), 13-24.

Fatmawati, R. A., Pradhanawati, A., \& Ngatno, N. (2016). Pengaruh Orientasi Pasar, Orientasi Kewirausahaan Terhadap Keunggulan Bersaing dan Kinerja Pemasaran Pada Warung Angkringan Kota Semarang. Jurnal Ilmu Administrasi Bisnis, 5(3), 351-362.

Ferdinand. (2014). Metode Penelitian Manajemen: Pedoman Penelitian untuk Penulisan Skripsi, Tesis, dan Disertasi Ilmu Manajemen (5th ed.). Badan Penerbit Universitas Diponegoro.

Gholami, S., \& Birjandi, M. (2016). The Effect of Market Orientation and Entrepreneurial Orientation on the Performance of SMEs. Jurnal Ilmu Administrasi Bisnis, 5(1), 361-369.

Guspul, A. (2016). Pengaruh Orientasi Pasar, Inovasi dan Orientasi Kewirausahaan terhadap Kinerja Pemasaran Umkm "Batako" Di Kepil Wonosobo. Jurnal Penelitian dan Pengabdian Kepada Masyarakat UNSIQ, 3(3).

Ibrahim, N. M. N., \& Mahmood, R. (2016). Mediating Role of Competitive Adventage on the Relationship Between Entrepreneurial Orientation and the Performance of Small and Medium Enterprise. Journals International Business Management, 10(1), 2444-2452.

Killa, M. F. (2014). Effect of Entrepreneurial Innovativeness Orientation, Product Innovation, and Value Co-Creation on Marketing Performance. Journal of Research in Marketing, 2(3), 198-204.
Leal-Rodríguez, A. L., \& Albort-Morant, G. (2016). Linking Market Orientation, Innovation and Performance: An Empirical Study on Small Industrial Enterprises in Spain. Journal of Small Business Strategy, 26(1), 37-50.

Lumpkin, G. T., \& Dess, G. G. (1996). Clarifying the Entrepreneurial Orientation Construct and Linking it to Performance. Academy of Management Review, 21(1), 135-172.

Mustikowati, R. I., \& Tysari, I. (2014). Orientasi Kewirausahaan, Inovasi, Dan Strategi Bisnis Untuk Meningkatkan Kinerja Perusahaan (Studi Pada Ukm Sentra Kabupaten Malang). Jurnal Ekonomi MODERNISASI, 10(1), 23-37.

Pardi, S., Imam, S., \& Zainul, A. (2014). The Effect of Market Orientation and Entrepreneurial Orientation toward Learning Orientation, Innovation, Competitive Advantages and Marketing Performance. European Journal of Business and Management, 6(21), 69-80.

Setiawan, H. (2015). Pengaruh Orientasi Pasar, Budaya Organisasi, dan Orientasi Kewirausahaan Terhadap Kinerja Usaha (Studi pada Usaha Kecil Pengolahan di Kota Palembang). Jurusan Administrasi Bisnis Politeknik Negeri Sriwijaya, 13(2), 152-165.

Suendro, G. (2010). Analisis Pengaruh Inovasi Produk Melalui Kinerja Pemasaran Untuke Mencapai Keungsulan Bersaing Berkelanjutan (Studi kasus pada Industri Kecil dan Menengah Batik Pekalongan). Universitas Diponegoro, Semarang.

Suliyanto, \& Rahab. (2012). The Role of Market Orientation and Learning Orientation in Improving Innovativeness and Performance of Small and Medium Enterprises. Asian Social Science, 8(1), 134 145. 
Tung, J. (2012). A Study Of Product Innovation On Firm Performance. The International Journal of Organizational Innovation, 4(3), 83-97.

Utaminingsih, A. (2016). Pengaruh orientasi pasar, inovasi, dan kreativitas strategi pemasaran terhadap kinerja pemasaran pada ukm kerajinan rotan di desa teluk wetan, welahan, jepara. Media ekonomi dan manajemen, 31(2), 77-87.
Yeni, Y. H., Luthan, E., Hastini, L. Y., \& Primasari, A. (2014). Pemberdayaan Industri Kreatif Sektor Kerajinan di Sumatera Barat Melalui Entrepreneurial Marketing; Studi pada UMKM Bordir dan Sulaman. Jurnal Aplikasi Manajemen, 12(3), 478-491. 